\title{
Phytoplankton photosynthesis-irradiance parameters in the near-shore UK coastal waters of the North Sea: temporal variation and environmental control
}

\author{
Peter J. Shaw*, Duncan A. Purdie \\ School of Ocean and Earth Science, University of Southampton, Southampton Oceanography Centre, European Way, \\ Southampton SO14 3ZH, United Kingdom
}

\begin{abstract}
Chlorophyll-specific photosynthesis-irradiance $(P-E)$ parameters of natural phytoplankton in the near-shore UK coastal waters of the North Sea were determined during six 2 wk surveys carried out from 1993 to 1995 . The initial slope of the $P-E$ curve $\left(\alpha^{\mathrm{B}}\right)$ varied from 0.02 to $2.44 \mathrm{mg} \mathrm{C}$ $\mathrm{mg}^{-1} \mathrm{chl} \mathrm{a} \mathrm{d} \mathrm{d}^{-1}$ ( $\mathrm{mol}$ photons $\left.\mathrm{m}^{-2} \mathrm{~s}^{-1}\right)^{-1}$ between winter 1993 and October 1994; the light-saturated

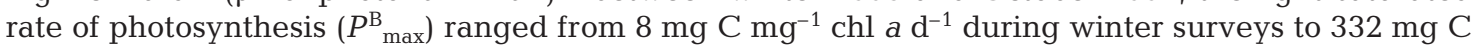
$\mathrm{mg}^{-1} \mathrm{chl} \mathrm{a} \mathrm{d}^{-1}$ during October 1994. Values of $\alpha^{\mathrm{B}}$ and $P^{\mathrm{B}}{ }_{\text {max }}$ determined during October 1994 were significantly higher than in other survey periods. Although phytoplankton cell biomass was significantly higher during the June 1995 survey (due to high abundance of Phaeocystis spp. at some sites) than in October or winter surveys, the October peak in $P$-E parameters coincided with a period in which dinoflagellates accounted for a high proportion of phytoplankton carbon biomass. Multiple linear regression analysis revealed that $\alpha^{\mathrm{B}}$ could be predicted from the total photosynthetically available radiation (PAR) incident at the surface during the daylight period, whilst $P^{\mathrm{B}}{ }_{\max }$ could be predicted from a linear combination of total incident PAR and sea-surface temperature. Temporal variations of $\alpha^{\mathrm{B}}$ and $P^{\mathrm{B}}{ }_{\max }$ did not result in significant temporal variation of the light-saturation onset parameter $\left(E_{\mathrm{k}}\right)$ and the overall mean value of $E_{\mathrm{k}}$ was $176 \pm 6 \mu \mathrm{mol}$ photons $\mathrm{m}^{-2} \mathrm{~s}^{-1}$. The high turbidity of nearshore surface waters of the western North Sea appears to restrict penetration of irradiance to the extent that phytoplankton are not exposed to PAR levels at which photoadaptation of their photosynthetic apparatus is induced.
\end{abstract}

KEY WORDS: Primary production $\cdot$ Phytoplankton $\cdot$ Photosynthesis $\cdot$ Coastal $\cdot$ North Sea

\section{INTRODUCTION}

The response of phytoplankton to the highly variable conditions encountered in near-shore coastal waters such as those of the North Sea is not well understood. In the estuaries and near-shore waters of the northeast UK North Sea, levels of important phytoplankton nutrients such as nitrogen and phosphorus are often high,

*Present address: Centre for Environmental Sciences, University of Southampton, Highfield, Southampton SO17 1BJ, United Kingdom. E-mail: p.j.shaw@soton.ac.uk whilst turbidity is extremely variable (Holligan et al. 1989, NERC 1992). Low levels of light penetration into the water column in turbid estuaries do not necessarily preclude the occurrence of appreciable rates of photosynthesis (Joint \& Pomroy 1981, Fichez et al. 1992). If photosynthesis can take place at appreciable rates within the highly turbid water of the Humber estuary and its plume (Morris 1988, NRA 1993), then the high concentrations of nitrogen and phosphorus in these same waters (Morris 1988, NERC 1992, NRA 1993) may be sufficient to support high levels of phytoplankton biomass. In contrast, surface waters in other re- 
gions within UK North Sea coastal waters have relatively low concentrations of suspended particulate material (Holligan et al. 1989), allowing deeper penetration of light. Under such conditions, the higher availability of light can potentially lead to high rates of photosynthetic production, but only if available nutrients are sufficient to support the synthesis of new phytoplankton biomass. Concentrations of available nitrogen and phosphorus in the UK coastal regions of the North Sea tend to be lower in waters of low turbidity than waters of high turbidity (Brockmann et al. 1990, NERC 1992) and may therefore not be sufficient to support high rates of phytoplankton growth. In particular, the dilution of nutrient-rich and turbid estuarine discharge by clearer coastal waters with lower nutrient concentrations generates steep and opposing gradients of light and nutrient availability within the plume of the Humber estuary.

High rates of phytoplankton growth in near-shore marine environments may be associated with blooms of 'nuisance' phytoplankton (Joint \& Pomroy 1981, Reid et al. 1990). If the occurrence of such blooms is to be predicted, it is important that the response of phytoplankton growth to changes in the physical and chemical conditions (e.g. irradiance, turbidity and nutrient availability) is understood, particularly in coastal waters in which conditions are highly variable. It should also be considered that the quantities of dissolved nutrients available to phytoplankton in more offshore regions can be reduced as a result of phytoplankton nutrient assimilation in estuaries and near-shore coastal waters (Sanders et al. 1997a,b, Shaw et al. 1998a,b). Distributions of phytoplankton biomass and production in the western North Sea are known to be extremely heterogeneous and tend to be observed in discrete and mobile patches (Horwood 1978, 1982, Horwood et al. 1982, Holligan et al. 1989, Joint \& Pomroy 1993). Given the variability of factors such as light and nutrient availability in the near-shore UK coastal waters of the North Sea and their importance for phytoplankton, it is likely that phytoplankton photosynthesis in this region is controlled by environmental variables.

Considerable research effort has been devoted to quantifying the relationship between phytoplankton photosynthesis and growth with light (e.g. Prézelin \& Matlick 1980, Gilstad et al. 1993) and nutrients (e.g. Cullen et al. 1992). Differences in the responses of phytoplankton to environmental variables have been identified, but largely under controlled laboratory conditions and with cultures of single phyto- plankton species (e.g. Falkowski et al. 1985, Langdon 1988, Cullen et al. 1992). Survey-based studies of European seas have focused on areal production rates (e.g. Gieskes \& Kraay 1984, Joint \& Pomroy 1993, Gowen \& Bloomfield 1996, Tillmann et al. 2000) rather than the environmental variables which control or limit the photosynthetic activity of natural phytoplankton assemblages, as has been shown in other coastal waters (e.g. Harrison \& Platt 1980, Côté \& Platt 1983, 1984).

The aim of this study was to determine the variability of photosynthesis-irradiance $(P-E)$ relationships of natural phytoplankton assemblages sampled throughout UK near-shore North Sea coastal waters over different seasons and to identify the environmental variables causing the temporal variations of $P$-E parameters.

\section{METHODS}

Survey cruises of 2 wk duration were conducted during November and December 1993, October 1994 and April, June and July 1995. Experiments to determine primary production were carried out daily at locations within a narrow coastal strip (30 km wide) encompassing near-shore coastal waters of the North Sea from the Scottish border to East Anglia (Fig. 1). Samples for production experiments were collected from a depth of $5 \mathrm{~m}$ using Go-Flo or Niskin bottles with Teflon-coated springs mounted on a CTD rosette.

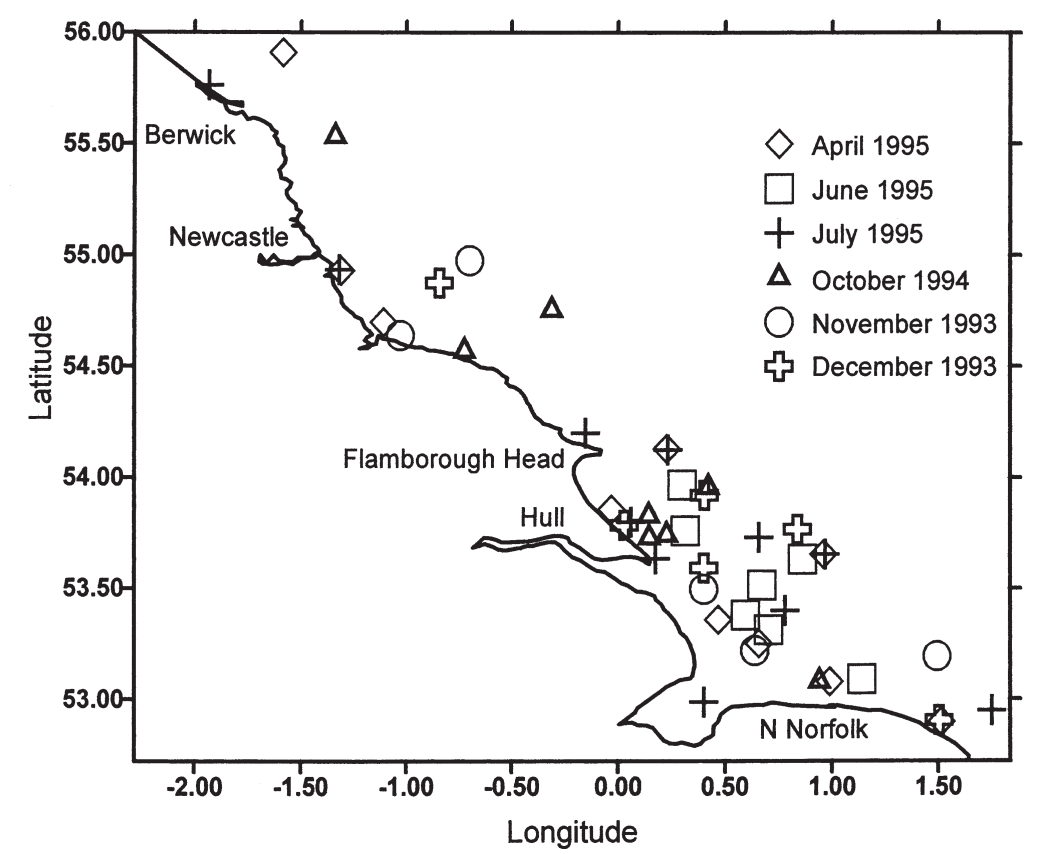

Fig. 1. Locations at which samples were collected for determination of production rates 
Concentrations of dissolved nutrients were determined spectrophotometrically. Phosphate, ammonium, nitrate and urea were determined in discrete samples collected directly from the CTD sampling rosette. Dissolved phosphate concentrations were measured using the molybdate and ascorbic acid method (Parsons et al. 1984). Ammonium concentrations were determined by the sodium nitrocyanoferrate and phenol method (Parsons et al. 1984). Concentrations of urea were determined using the diacetylmonoxime and thiosemicarbazide method (Mulvenna \& Savidge 1992). Nitrate was determined by shipboard autoanalyser (Skalar) using a sulphanilamide and N-(l-naphthyl)-ethylenediamine method (Parsons et al. 1984).

Measurements of surface water temperature, salinity and attenuation were made using instrumentation mounted on the Ship's CTD rosette (Neil Brown Instruments). Attenuation was measured at $660 \mathrm{~nm}$ using a transmissometer with a path length of $10 \mathrm{~cm}$ (Neil Brown Instruments). Surface incident photosynthetically available radiation (PAR) was continually measured with a shipboard sensor $(4 \pi)$, and the position of the ship was recorded by GPS navigation equipment.

Chlorophyll a (chl a) was measured on water samples filtered through $0.2 \mu \mathrm{m}$ pore size polycarbonate membrane filters (Millipore). The filters were stored frozen and then subsequently extracted in $90 \%$ acetone; the fluorescence was measured using a Turner Designs Model 10 fluorometer before and after addition of 2 drops of $10 \% \mathrm{HCl}$ (Lorenzen 1966). The fluorometer was calibrated with a pure chl a standard solution (Sigma), the concentration of which was determined spectrophotometrically (Parsons et al. 1984). Replicate samples of $100 \mathrm{ml}$ seawater were preserved with either Lugol's iodine or buffered $4 \%$ formalin (Parsons et al. 1984) and returned to the laboratory for inverted microscope analysis. Sub-samples (10 to $25 \mathrm{ml}$ ) were placed in sedimentation chambers and left to settle for at least $24 \mathrm{~h}$ prior to enumeration and identification of cells. Counts for individual species were converted to volume from measurements of cells (Kovala \& Larrance 1966) and then to cell carbon using the cell volume/carbon relationships given by Eppley et al. (1970) as described by Holligan et al. (1984). Cell carbon estimates of the individual species identified were subsequently grouped to enable quantification of the contributions of major groups (diatoms, flagellates, dinoflagellates, coccolithophores, ciliates or heterotrophic dinoflagellates) to total cell carbon.

Primary production measurements were made at 1 location $\mathrm{d}^{-1}$ (Fig. 1) using the on-deck simulated in situ incubation system of Joint \& Pomroy (1993) or an adaptation of this system. The adapted system consisted of 6 shallow plastic boxes secured to an unshaded area of the ship's deck. Surface seawater was pumped through the incubator boxes to maintain them at ambient sea-surface temperature. Each of 5 boxes was covered with a Perspex sheet enclosing a neutral filter of different density. The sixth box was left uncovered to give a series of boxes with a range of light transmissions at $100,60,30,16,3$ and $0.3 \%$ of ambient light. The original system of Joint \& Pomroy (1993) consisted of Perspex tubes with neutral density filters giving 97 , $75,36,21,6$ and $1 \%$ of ambient light with surface seawater pumped through to maintain surface seawater temperature.

For each production experiment, a sample was taken $1 \mathrm{~h}$ before dawn from a depth of $5 \mathrm{~m}$. Aliquots of $60 \mathrm{ml}$ were transferred to $60 \mathrm{ml}$ polycarbonate bottles and inoculated with $185 \mathrm{kBq} \mathrm{NaH}{ }^{14} \mathrm{CO}_{3}$ (Amersham International). Three bottles were placed in each of the on-deck incubation units, and 3 further bottles were placed in a temperature-controlled light-proof box. The samples were incubated from dawn to dusk and then transferred to a dark container (again maintained at sea-surface temperature) for the hours of darkness. After a $24 \mathrm{~h}$ light/dark incubation, each sample was filtered $(0.2 \mu \mathrm{m}$ pore size polycarbonate membrane, Millipore), rinsed with $15 \mathrm{ml}$ of filtered seawater and transferred to a plastic scintillation vial. The activity of the ${ }^{14} \mathrm{C}$ added to each of the incubated samples was determined by pipetting separate $60 \mu \mathrm{l}$ aliquots of the $\mathrm{NaH}^{14} \mathrm{CO}_{3}$ solution to each of 3 plastic scintillation vials to which $60 \mu \mathrm{l}$ of ethyl ethylamine was added as a trapping agent. A $4 \mathrm{ml}$ aliquot of scintillation fluor was added (Optiphase HiSafe: Wallac) to each vial and the ${ }^{14} \mathrm{C}$ content of the filter retentate determined using a liquid scintillation counter (Wallac 1411) calibrated using an external standard, channels ratio method.

Parameters describing the relationship between photosynthesis $(P)$ and irradiance $(E)$ were determined by fitting experimentally derived production rates to the equation of Webb et al. (1974) by means of an iterative non-linear regression programme (SigmaPlot: Jandel Scientific). Although numerous mathematical models of the $P$-E curve have been developed (Jassby \& Platt 1976), there appears to be little advantage in selecting any particular model (Lederman \& Tett 1981) unless inhibition of production occurs at higher levels of irradiance. Pronounced photoinhibition of production at higher levels of PAR was not evident in any of the experiments, and the equation of Webb et al. (1974) was appropriate to model the $P-E$ curves derived. The slope of the initial part of the $P$-E curve is denoted $\alpha$ and indicates the efficiency with which incident light energy is converted into photosynthetic production by the phytoplankton community. The maximum photosynthetic carbon production rate attained $\left(P_{\max }\right)$ indicates the light-saturated photosynthetic rate. 
Irradiance for each of the separate incubator boxes was taken as the mean of PAR recorded during the daylight part of the incubation period and scaled according to the light transmission of the neutral density filters placed over each box. Values of $P$ determined during in situ incubations using the ${ }^{14} \mathrm{C}$ technique were not corrected for dark uptake, but ${ }^{14} \mathrm{C}$ uptake rates at all 7 PAR levels (dark to 97 or $100 \%$ incident PAR) were used to determine values of $\alpha$ and $P_{\text {max }}$. Derived $P$-E parameters were normalized to phytoplankton biomass to enable direct comparison of photosynthetic rates. Values of $\alpha$ and $P_{\max }$ normalized to chl a are denoted by $\alpha^{\mathrm{B}}$ and $P_{\text {max }}^{\mathrm{B}}$, respectively.

\section{RESULTS}

\section{Temporal variation of photosynthetic parameters}

Variation of photosynthetic parameters on a temporal basis was investigated by comparing mean $\alpha^{\mathrm{B}}$ and $P^{\mathrm{B}}$ max values. Mean chl a-normalized photosynthetic parameters were higher during October 1994 than in other surveys (Fig. 2A,B). Values of $\alpha^{\mathrm{B}}$ were not normally distributed and statistical comparison (KruskalWallis 1-way ANOVA on ranks) indicated statistically significant differences between median $\alpha^{\mathrm{B}}$ values for the different surveys. Pairwise multiple comparison (Dunn's method) isolated only 2 pairs of surveys (October 1994 and April 1995; October 1994 and June 1995) as significantly different at the $p<0.05$ level. Values of $P_{\text {max }}^{\mathrm{B}}$ for each survey were normally distributed and statistical comparison (1-way ANOVA) indicated significant differences between the survey means. Surface incident irradiance levels during December 1993 were insufficient for photosynthesis to reach an asymptote in all except 1 of the 6 incubation experiments conducted. The curve-fitting procedure used thus produced only 1 reliable estimate of $P^{\mathrm{B}}{ }_{\max }$ and 1 corresponding value of the light-saturation onset parameter $\left(E_{\mathrm{k}}\right)$ for December 1993 (Fig. 2). Isolation of the surveys which differed in terms of mean $P^{\mathrm{B}}$ max by pairwise multiple comparison (Tukey test) showed that the high values of $P^{\mathrm{B}}{ }_{\text {max }}$ observed during October 1994 (Fig. 2B) were significantly different $(p<0.05)$ to those measured during other surveys. No other pairs of surveys were significantly different in terms of $P_{\text {max }}^{\mathrm{B}}$.

$P$ - $E$ curves generated from ${ }^{14} \mathrm{C}$ production measurements were also quantified by calculation of $E_{\mathrm{k}}$ as the ratio of $P_{\max }$ to $\alpha$ (Talling 1957). Mean values of $E_{\mathrm{k}}$ during the surveys conducted in June 1994 and November 1993 were relatively high compared to other months, and the standard error of the means indicated that $E_{\mathrm{k}}$ was more variable during these periods (Fig. 2C). Values of $E_{\mathrm{k}}$ for surveys were not normally distributed, and
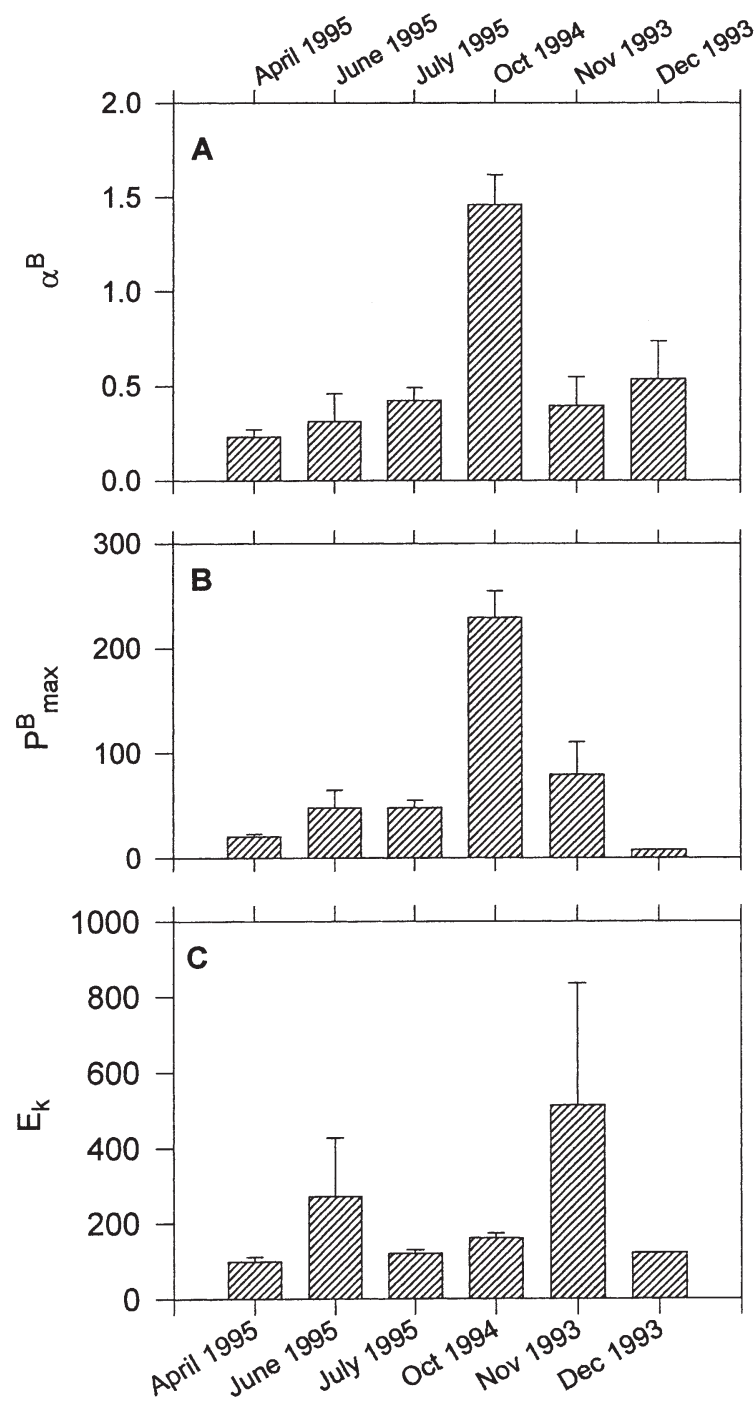

Fig. 2. Mean chl a-specific photosynthetic parameters $\alpha^{\mathrm{B}}$ (mg $\left.\mathrm{C} \mathrm{mg}^{-1} \mathrm{chl} \mathrm{a} \mathrm{d}^{-1}\left[\mu \mathrm{mol} \text { photons } \mathrm{m}^{-2} \mathrm{~s}^{-1}\right]^{-1}\right), P^{\mathrm{B}}{ }_{\max }\left(\mathrm{mg} \mathrm{C} \mathrm{mg}^{-1}\right.$ chl $a \mathrm{~d}^{-1}$ ) and light-saturation onset irradiance, $E_{\mathrm{k}}$ ( $\mu \mathrm{mol}$ photons $\mathrm{m}^{-2} \mathrm{~s}^{-1}$ ) determined in experiments carried out during each of the 6 survey cruises. Vertical bars show standard error. One value only of $P^{\mathrm{B}}{ }_{\max }$ and $E_{\mathrm{k}}$ is shown for December 1993

although statistical comparison (Kruskal-Wallis 1-way ANOVA on ranks) indicated significant differences in the median values of $E_{\mathrm{k}}$, pairwise multiple comparison (Dunn's method) did not indicate any survey to be significantly different to another.

\section{Temporal variation of phytoplankton biomass and community composition}

Temporal changes in phytoplankton were considered by comparing mean cellular carbon biomass and community composition for each survey together with chl a 
concentration. Phytoplankton samples from the survey conducted in December 1993 were not available for enumeration. Mean chl a concentrations (Fig. 3A) were highest during June $1995\left(2.8 \pm 0.8 \mathrm{mg} \mathrm{m}^{-3}\right)$ and particularly low during the winter surveys $\left(<0.2 \mathrm{mg} \mathrm{m}^{-3}\right)$. Cell carbon concentrations also indicated relatively high biomass during June 1995 (Fig. 3B,C). Variations of phytoplankton carbon (Fig. 3C) between surveys followed a similar seasonal pattern to chl a (Fig. 3A).
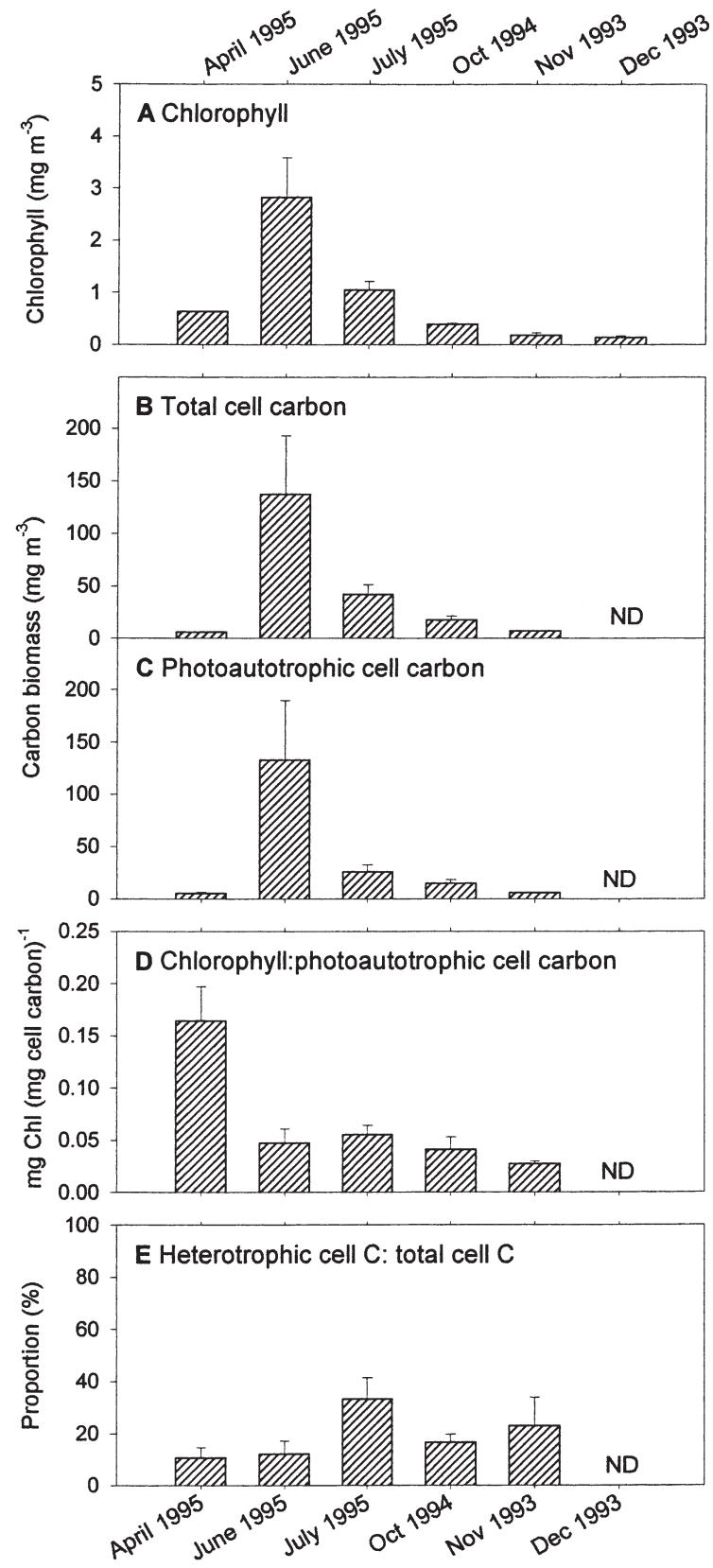

Fig. 3. (A-C) Mean phytoplankton biomass, (D) mean ratios of chl a to cell carbon and (E) heterotrophic to total cell carbon for each of the survey cruises. ND: not determined; vertical bars show standard error
Variations of phytoplankton carbon biomass and chl a between surveys were analysed using ANOVA and pairwise multiple comparison tests (1-way ANOVA and Tukey tests for normally distributed data; KruskalWallis 1-way ANOVA and Dunn's method for data not normally distributed). Median chl a concentration in summer surveys (June and July 1995) was significantly different to median values observed during October 1994 and November and December 1993 (Table 1). A significant difference between median chl a concentration in April 1995 and December 1993 was also identified (Table 1). Despite the apparent marked difference in chl a concentration, total cell carbon and photoautotrophic cell carbon between June and July 1995 (Fig. 3A-C), differences in median values were not significant (Table 1).

Mean ratios of chl a to photoautotrophic cell carbon were similar throughout most of the surveys, but were markedly higher during the survey in April 1995 (Fig. 3D). Mean ratios of heterotrophic cell carbon to total cell carbon varied little between most surveys, with heterotrophic species accounting for 11 to $16 \%$ of the total cell carbon in April and June 1995, October 1994 and November 1993 (Fig. 3E). In July 1995, photoautotrophic phytoplankton species accounted for only $66 \%$ of total cell carbon (Fig. 3E) due to heterotrophic species comprising a major fraction of the total cell carbon ( 71 to $76 \%$ ) in 3 of the 11 production experiments conducted.

When tested statistically using ANOVA and pairwise multiple comparison procedures, the median ratio of chl a to photoautotrophic cell carbon was significantly different between the April 1995 survey and the June 1995 and October 1994 surveys (Table 1). A significant difference of the mean proportion of photoautotrophic cell carbon was identified only between April and July 1995 (Table 1).

The composition of the phytoplankton was first considered in terms of the mean proportion of the total biomass accounted for by major groups (Fig. 4). Diatoms were present at appreciable levels (i.e. $>10 \%$ of total cell carbon) in all surveys, whilst the mean proportion of dinoflagellates varied markedly between surveys, reaching a maximum in October (Fig. 4). Flagellate biomass was higher than for other major groups during all survey periods except October, but accounted for a relatively small proportion $(<30 \%)$ of the total plankton biomass in July 1995 (Fig. 4). Heterotrophs (ciliates and heterotrophic dinoflagellates) comprised a smaller proportion of the total cell biomass than the photoautotrophic phytoplankton (Fig. 4). Coccolithophores and other groups accounted for negligible proportions $(<1 \%)$ of the total phytoplankton biomass during all survey periods. 
Table 1. Summary of statistical differences between phytoplankton biomass measures and ratios. Variables for which differences between means or medians were significant $(\mathrm{p}<0.05)$ are shown as follows. Upper diagonal: Chlorophyll median (Chl), median total cell carbon $\left(\mathrm{C}_{\mathrm{T}}\right)$, median photoautotrophic cell carbon $\left(\mathrm{C}_{\mathrm{PH}}\right)$. Lower diagonal: median ratio of $\mathrm{chl}$ a to photoautotrophic cell carbon $\left(\mathrm{Chl}: \mathrm{C}_{\mathrm{PH}}\right)$, mean photoautotrophic cell carbon as a proportion of total cell carbon $\left(\mathrm{C}_{\mathrm{PH}} \%\right)$

\begin{tabular}{|c|c|c|c|c|c|c|}
\hline & Apr 1995 & Jun 1995 & Jul 1995 & Oct 1994 & Nov $1993^{a}$ & Dec $1993^{a}$ \\
\hline Apr 1995 & & $\mathrm{C}_{\mathrm{T}}$ & $\begin{array}{l}\mathrm{C}_{\mathrm{T}} \\
\mathrm{C}_{\mathrm{T}}\end{array}$ & - & - & Chl \\
\hline Jun 1995 & Chl: $\mathrm{C}_{\mathrm{PH}}$ & & - & $\mathrm{Chl}$ & $\mathrm{Chl}$ & Chl \\
\hline Jul 1995 & $\mathrm{C}_{\mathrm{PH}} \%$ & - & & $\mathrm{Chl}$ & $\mathrm{Chl}$ & $\mathrm{Chl}$ \\
\hline Oct 1994 & Chl: $\mathrm{C}_{\mathrm{PH}}$ & - & - & & - & - \\
\hline Nov $1993^{a}$ & ND & ND & ND & ND & & - \\
\hline Dec $1993^{a}$ & ND & ND & ND & ND & ND & \\
\hline
\end{tabular}

The dominant groups and individual species of phytoplankton enumerated in experimental samples collected during the spring and summer surveys in 1995 and autumn 1994 are shown in Table 2. Phytoplankton samples were not enumerated from the majority of experimental stations during November and December 1993 surveys; however, a number of additional surface samples were counted during the November survey. These samples indicated that in most areas of the survey region, flagellates formed a high proportion of the photoautotrophic carbon (30 to $80 \%$ ) in November, with diatoms and dinoflagellates accounting for 10 to $40 \%$ of the phytoplankton carbon. Few individual species of dia-

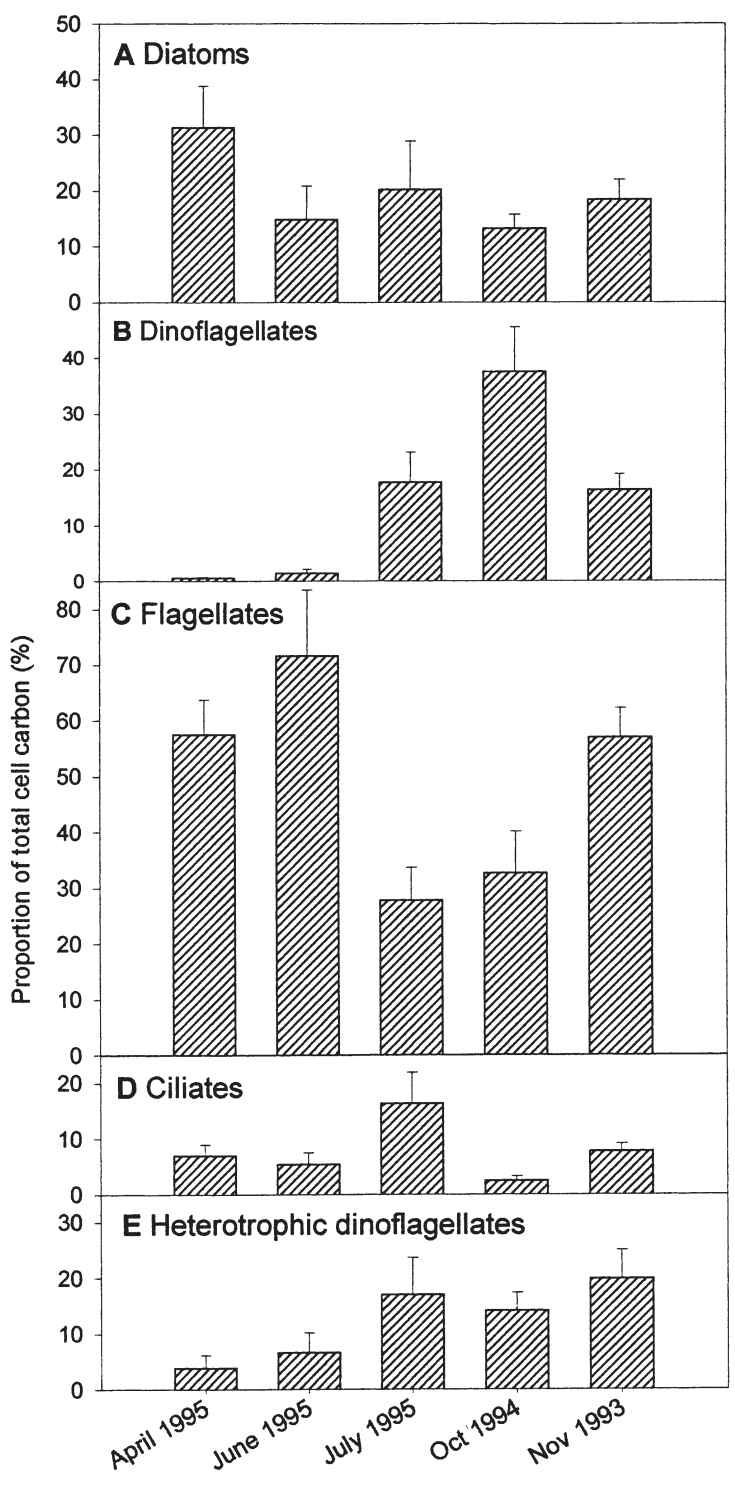

toms or dinoflagellates represented $>10 \%$ of total phytoplankton biomass at any of the stations sampled in November. In April, prior to the spring bloom, phytoplankton biomass was low $\left(<10 \mathrm{mg} \mathrm{m}^{-3}\right.$ cellular carbon) in comparison to other months (Fig. 3B). Diatoms represented $>10 \%$ of phytoplankton carbon at 7 of the 9 stations counted, with dominant species being Coscinodiscus concinnus (2 stations), Pleurosigma sp. (3 stations) and Thalassiosira cf. rotula (1 station) (Table 2). In April, dinoflagellates were absent or present in very low abundance $(<5 \%$ of phytoplankton carbon) at all stations, whereas flagellates represented between 20 and $90 \%$ of the total phytoplankton biomass at all 9 stations counted. In early June all experimental samples were within the region south of Flamborough Head (Fig. 1). One additional surface sample collected offshore of Berwick-upon-Tweed was counted and revealed $>75 \%$ of the phytoplankton biomass to be dominated by diatoms (mainly Leptocylindricus minimum), although the total phytoplankton carbon biomass was low $\left(14 \mathrm{mg} \mathrm{m}^{-3}\right)$. Stations to the north of the Humber mouth also had low carbon biomass $(<33 \mathrm{mg}$ $\mathrm{m}^{-3}$ ) and chl a concentration $\left(<1.4 \mathrm{mg} \mathrm{m}^{-3}\right)$ but were dominated by diatoms, notably Asterionella glacialis and Lauderia annulata (Table 2). These stations also had a high proportion of heterotrophic carbon (14 to $37 \%$ ) and a high proportion of flagellates, although these were not Phaeocystis cells. This observation was in contrast to the 4 stations to the southeast of the

Fig. 4. Mean composition of the microplankton for each survey cruise shown as the proportion of total cell carbon biomass accounted for by each of the major microplankton groups identified. Vertical bars show standard error. Microplankton samples for December 1993 were not available for microscopic analysis 
Table 2. Important phytoplankton groups and species contributing to cellular biomass during survey cruises. The number of experimental samples is shown in which cellular carbon of each group or species accounts for $>10 \%$ of total photoautotrophic carbon

\begin{tabular}{|c|c|c|c|c|}
\hline \multicolumn{2}{|c|}{ Survey date: Apr 199} & \multicolumn{3}{|c|}{ Jun 1995 Jul 1995 Oct 1994} \\
\hline Experimental samples: & $9^{\mathrm{a}}$ & 7 & 11 & 8 \\
\hline Diatoms & 7 & 3 & 5 & 6 \\
\hline Asterionella glacialis & - & 1 & 1 & - \\
\hline Coscinodiscus concinnus & 2 & - & 1 & - \\
\hline Lauderia annulata & - & 2 & - & - \\
\hline Leptocylindricus danicus & - & - & 1 & - \\
\hline Pleurosigma sp. & 3 & - & & - \\
\hline Rhizoselenia alata & - & - & 1 & - \\
\hline Rhizoselenia delicatula & - & - & 2 & - \\
\hline Thalassiosira cf. rotula & 1 & - & - & - \\
\hline Dinoflagellates & - & - & 7 & 7 \\
\hline Ceratium furca & - & - & - & 3 \\
\hline Ceratium lineatum & - & - & 4 & 1 \\
\hline Ceratium tripos & - & - & 1 & - \\
\hline Dinophysis acuta & - & - & - & 5 \\
\hline Dinophysis acuminata & - & - & 2 & - \\
\hline Katodinium rotundatum & - & - & 3 & - \\
\hline Flagellates & 9 & 7 & 10 & 8 \\
\hline Flagellates $4 \mu \mathrm{m}$ & 9 & 3 & 8 & 7 \\
\hline Flagellates $2 \mu \mathrm{m}$ & 6 & 1 & 4 & 2 \\
\hline Cryptomonad & 4 & 1 & 4 & 2 \\
\hline Phaeocystis & - & 4 & - & - \\
\hline Coccolithophores & - & - & 1 & - \\
\hline
\end{tabular}

Humber mouth in the outer plume region, at which Phaeocystis cells dominated the photoautotrophic carbon (80 to $95 \%$ ) and chl a (ca $4.5 \mathrm{mg} \mathrm{m}^{-3}$ ) and similarly cell carbon concentrations (ca $350 \mathrm{mg} \mathrm{m}^{-3}$ ) were elevated. At all stations sampled in June, dinoflagellates formed a very small proportion of the total photoautotrophic carbon.

In early July, the 5 stations sampled northwest of the Humber mouth had high numbers of dinoflagellates, including Ceratium lineatum, Ceratium tripos, Dinophysis acuminata and Katodinium rotundatum (Table 2) and represented $>45 \%$ of the photoautotrophic carbon. At stations south of the Humber plume, diatoms were more abundant and each of the following species represented $>10 \%$ of the photoautotrophic carbon: Asterionella glacialis (1 station), Coscinodiscus concinnus (1 station), Leptocylindricus danicus (1 station), Rhizosolenia delicatula (2 stations) and Rhizosolenia alata (1 station). Flagellates were gen- erally present at high proportions closer to the Humber mouth. At one station, east of Flamborough Head, coccolithophores contributed $>10 \%$ to phytoplankton carbon, with Syracosphaera sp. and Emiliania huxleyi being most abundant. At 9 of the 11 stations sampled, heterotrophic carbon represented $>10 \%$ of total carbon and at 3 more northerly near-shore stations this proportion increased to $>70 \%$.

During the autumn survey in October 1994, although 6 of the 8 stations sampled had $>10 \%$ diatom carbon as a proportion of phytoplankton carbon, no single species dominated at any station. Chl a $\left(<0.6 \mathrm{mg} \mathrm{m}^{-3}\right)$ and phytoplankton carbon levels $\left(<35 \mathrm{mg} \mathrm{m}^{-3}\right)$ were low during this survey. However, dinoflagellates were present at 7 out of the 8 stations at $>10 \%$ of phytoplankton carbon and accounted for $>50 \%$ of phytoplankton carbon at 4 stations, with dominant species being Ceratium furca, Ceratium lineatum and Dinophysis acuta (Table 2). Flagellate carbon was variable (15 to $80 \%$ ) at the different stations during October, but Phaeocystis cells were not present in any of the samples counted.

\section{Relationships of photosynthetic parameters with environmental variables}

Relationships of photosynthetic parameters with environmental variables were quantified using multiple linear regression analysis. A forward selection procedure (Kleinbaum et al. 1998) was adopted in which correlation tests (Pearson product moment) were first conducted to determine the environmental variable most highly correlated (i.e. highest r) with each photosynthetic parameter (Table 3 ). The statistical significance ( $p$ value) of the most highly correlated variable as a predictor of each photosynthetic parameter was then

Table 3. Correlation coefficients ( $\mathrm{r}$ ) and $\mathrm{p}$ values (in parentheses) for relationships between photosynthesis parameters and environmental variables (NS: not significant, $\mathrm{p}>0.05)$. PAR: photosynthetically available radiation

\begin{tabular}{|lccc|}
\hline Variable & $\alpha^{\mathrm{B}}$ & $P^{\mathrm{B}}{ }_{\max }$ & $E_{\mathrm{k}}$ \\
\hline Mean PAR & $-0.618(<0.001)$ & $-0.610(<0.001)$ & $-0.170^{\mathrm{NS}}$ \\
Total PAR & $-0.652(<0.001)$ & $-0.670(<0.001)$ & $-0.131^{\mathrm{NS}}$ \\
Attenuation & $-0.234^{\mathrm{NS}}$ & $-0.270^{\mathrm{NS}}$ & $-0.191^{\mathrm{NS}}$ \\
Temperature & $0.327^{\mathrm{NS}}$ & $0.340(0.046)$ & $0.074^{\mathrm{NS}}$ \\
{$\left[\mathrm{PO}_{4}{ }^{3-}\right]$} & $0.020^{\mathrm{NS}}$ & $-0.014^{\mathrm{NS}}$ & $-0.130^{\mathrm{NS}}$ \\
{$\left[\mathrm{NH}_{4}{ }^{+}\right]$} & $0.095^{\mathrm{NS}}$ & $-0.012^{\mathrm{NS}}$ & $-0.294^{\mathrm{NS}}$ \\
{$\left[\mathrm{NO}_{3}{ }^{-}\right]$} & $-0.147^{\mathrm{NS}}$ & $-0.178^{\mathrm{NS}}$ & $-0.156^{\mathrm{NS}}$ \\
{$\left[\mathrm{Urea}^{\mathrm{NS}}\right]$} & $0.354(0.040)$ & $0.360(0.040)$ & $-0.063^{\mathrm{NS}}$ \\
Diatom cell C & $0.008^{\mathrm{NS}}$ & $0.050^{\mathrm{NS}}$ & $0.201^{\mathrm{NS}}$ \\
Dinoflagellate cell C & $0.239^{\mathrm{NS}}$ & $0.255^{\mathrm{NS}}$ & $0.001^{\mathrm{NS}}$ \\
Flagellate cell C & $-0.182^{\mathrm{NS}}$ & $-0.197^{\mathrm{NS}}$ & $-0.048^{\mathrm{NS}}$ \\
Ciliate cell C & $-0.154^{\mathrm{NS}}$ & $-0.172^{\mathrm{NS}}$ & $0.109^{\mathrm{NS}}$ \\
Heterotrophic dinoflagellate cell C & $-0.121^{\mathrm{NS}}$ & $0.074^{\mathrm{NS}}$ & $0.089^{\mathrm{NS}}$ \\
$\mathrm{N}$ & 35 & 34 & 34 \\
\hline
\end{tabular}


determined. If the most highly correlated variable was found not to be a significant predictor of $\alpha^{\mathrm{B}}$, $P^{\mathrm{B}}{ }_{\max }$ or $E_{\mathrm{k}}(\mathrm{p}>0.05)$, it was concluded that none of the remaining and less correlated environmental variables were significant predictors of $\alpha^{\mathrm{B}}, P^{\mathrm{B}}{ }_{\max }$ or $E_{\mathrm{k}}$. If significant, the most highly correlated variable was included in the linear model and further variables contributing significantly to the prediction of the photosynthesis parameters were identified by an iterative procedure, in which only significant predictors were considered and variables with the lowest $p$ value included in the model at each iteration (Kleinbaum et al. 1998). Experimental data were included in this process only when a full set of photosynthetic parameters and environmental variables (Table 3) were available.

Both mean daylight incident PAR and total incident PAR were significantly correlated with $\alpha^{\mathrm{B}}$ and $P_{\text {max }}^{\mathrm{B}}$ (Table 3). However, co-linearity of mean PAR and total PAR was observed: total incident PAR was selected as the measure of PAR for consideration as a predictor of $\alpha^{\mathrm{B}}$ and $P_{\text {max }}^{\mathrm{B}}$ due to its higher correlation coefficient (Table 3). Multiple linear regression analysis identified that only total incident PAR contributed significantly to predicting the initial slope of the $P$ - $E$ curve $\left(\alpha^{\mathrm{B}}\right)$; no other environmental variables contributed significantly in this respect (Table 4 ). $P^{\mathrm{B}}$ max could also be predicted from the total incident PAR, but inclusion of seasurface temperature in the linear model gave a higher level of explained variance $\left(r^{2}=57 \%\right)$ and a lower standard error (Table 4). Although the concentration of urea was also significantly correlated with $\alpha^{\mathrm{B}}$ and $P^{\mathrm{B}}$ max (Table 3 ), this variable did not contribute significantly to the prediction of $\alpha^{\mathrm{B}}$ or $P_{\text {max }}^{\mathrm{B}}$ when included in linear models (Table 4 ). $E_{\mathrm{k}}$ was not significantly correlated with any of the environmental variables considered but was most strongly correlated to ammonium concentration (Table 3). Ammonium was not, however, found to be a significant predictor of $E_{\mathrm{k}}$ when assessed by multiple linear regression.

\section{DISCUSSION}

The mean chl a concentrations measured during the survey periods (Fig. 3) are comparable to those of previous reports for similar times of year. Chl a concentrations of less than $1 \mathrm{mg} \mathrm{m}^{-3}$ have previously been observed in UK North Sea coastal waters throughout winter and early spring, rising to $1-2 \mathrm{mg} \mathrm{m}^{-3}$ during autumn and $>2 \mathrm{mg} \mathrm{m}^{-3}$ during late spring to early summer (Horwood 1978, 1982, Joint \& Pomroy 1993).
Localized chl a patches in excess of $4 \mathrm{mg} \mathrm{m}^{-3}$ have also been observed adjacent to the estuaries of the Tees and Humber, the north Norfolk coast and Flamborough Head. These previous studies also showed evidence that chl a concentrations and production rates are high during late April, May and early June in these coastal waters. The results presented here from the first 2 wk of April 1995 do not indicate a clearly defined 'spring bloom' of phytoplankton, although diatoms were dominant particularly at more northerly stations and the high chl a:phytoplankton cell carbon in April (Fig. 3D) suggests the population was actively growing. Additional data collected in this region during mid- to late April (authors' unpubl. data) revealed chl a concentrations up to $30 \mathrm{mg} \mathrm{m}^{-3}$ in surface waters to the north of $54^{\circ} \mathrm{N}$, indicative of the diatom spring bloom, whereas below $54^{\circ} \mathrm{N}$ chl a concentrations were $<2 \mathrm{mg}$ $\mathrm{m}^{-3}$. These values are much higher than those detected by Joint \& Pomroy (1993) for this region, but it is likely that the peak of the spring bloom in 1989 occurred in mid- to late April, between their surveys. By early May, chl a concentrations north of $54^{\circ} \mathrm{N}$ had decreased again to mostly $<2 \mathrm{mg} \mathrm{m}^{-3}$, whereas south of $54^{\circ} \mathrm{N}$ values up to $50 \mathrm{mg} \mathrm{m}^{-3}$ were recorded (authors' unpubl. data), suggesting that growth of the spring bloom advances down the coast from north to south. In June $1995 \mathrm{chl}$ a values were elevated in the outer Humber plume due to the presence of Phaeocystis spp. (Table 2). This organism is well known to produce extensive blooms in the eastern and southern parts of the North Sea in May (Lancelot et al. 1991, Joint \& Pomroy 1993) but was not reported by Horwood (1982) as a major component of the phytoplankton in UK North Sea coastal waters. In July, chl a concentrations were low throughout the region, although at a station within The Wash, levels were elevated where Rhizosolenia delicatula dominated.

There have been few previous studies of seasonal changes in phytoplankton species abundance in UK coastal waters of the western North Sea. Horwood et al. (1982) found that the natural phytoplankton assemblages of this region were largely dominated by either diatoms or dinoflagellates during surveys in February to October 1976 and that dinoflagellates 
were most abundant during mid-summer (June/July) and autumn (September/October). The results from the current study broadly agree with their observations, although some differences in the dominant species of diatoms between the 2 studies exist. The method of collection of phytoplankton used by Horwood et al. (1982) (nylon filtering net with mesh aperture of $35 \mu \mathrm{m}$ ) would not have concentrated small flagellate species. Mills et al. (1994) included some phytoplankton data collected during spring surveys in 1989 from 2 stations: $\mathrm{CS}\left(55^{\circ} 30^{\prime} \mathrm{N}, 0^{\circ} 55^{\prime} \mathrm{E}\right)$ to the east of the northern sector of the current survey region and $\mathrm{AB}\left(52^{\circ} 42^{\prime} \mathrm{N}, 2^{\circ} 25^{\prime} \mathrm{E}\right)$ off the east coast of East Anglia, slightly to the south of the current survey region. Novarino et al. (1997) reported the presence or absence of dominant flagellates and dinoflagellates from a number of stations sampled throughout the North Sea but only one (Stn DF east of the Tees estuary) was within the region sampled as part of the current study. The dominant dinoflagellate species reported by Novarino et al. (1997) and Mills et al. (1994) are generally in agreement with Horwood et al. (1982) and results from the current study. The results of this study show that small flagellate species including Phaeocystis are also an important component of the phytoplankton in near-shore coastal waters of the western North Sea (Fig. 4).

This study has shown that chl a-normalized photosynthetic parameters were not significantly different in the near-shore UK coastal waters of the North Sea throughout most of the survey periods, but differed only during the October 1994 survey. Ranges of $\alpha^{\mathrm{B}}$ and $P^{\mathrm{B}}{ }_{\text {max }}$ measured during surveys from November 1993 to July 1995 compare closely to those previously reported for other regions of the North Sea (e.g. Tillmann et al. 2000) and fall within the ranges reported for a number of coastal environments (Keller 1988). Studies of $P$-E parameters of phytoplankton in nearshore coastal waters have identified that $\alpha^{\mathrm{B}}$ tends to vary little on a seasonal basis in the northern Irish Sea (Gowen \& Bloomfield 1996) or the North Friesian Wadden Sea (Tillmann et al. 2000). Marked seasonal variations of $\alpha^{\mathrm{B}}$ have, however, been reported for the Bedford Basin, Nova Scotia, by Côté \& Platt (1983). With regard to $P^{\mathrm{B}}{ }_{\max }$, the general lack of a marked seasonal variability observed in the present study corresponds closely to observations of Gowen \& Bloomfield (1996) in the northern Irish Sea. In contrast, marked seasonality of $P^{\mathrm{B}}$ max has been noted for phytoplankton in the Bedford Basin (Harrison \& Platt 1980, Côté \& Platt 1983) and in the North Friesian Wadden Sea (Tillmann et al. 2000). $E_{\mathrm{k}}$ showed no consistent seasonal pattern, with a mean value of $176 \pm 6 \mu \mathrm{mol}$ photons $\mathrm{m}^{-2} \mathrm{~s}^{-1}$. This mean is lower than the mean seasonal value reported by Tillmann et al. (2000) of
$216 \mu \mathrm{mol}$ photons $\mathrm{m}^{-2} \mathrm{~s}^{-1}$ but within the range reported for other coastal phytoplankton populations (Pennock \& Sharp 1986).

It should be noted, however, that Côté \& Platt's (1983) conclusions were based on daily measurements of $P$ - $E$ parameters rather than the less frequent surveys of the present study or, for example, that of Gowen \& Bloomfield (1996). We suggest that the lack of seasonal variability of $\alpha^{\mathrm{B}}$ and $P^{\mathrm{B}}$ max between the different survey periods observed in the present study and others (e.g. Gowen \& Bloomfield 1996) may be due in part to the relatively low number of incubation experiments which can be conducted during survey cruises: more frequent and numerous experiments would provide more extensive data which may identify a statistically significant seasonal signal in $P$-E parameters, such as has been observed for $\alpha^{\mathrm{B}}$ (Côté \& Platt 1983) and $P_{\text {max }}^{\mathrm{B}}$ (Côté \& Platt 1983, Tillmann et al. 2000) when a more frequent sampling programme was employed.

Laboratory culture experiments have identified several environmental factors (e.g. temperature, nutrient availability and irradiance) which lead to variation in phytoplankton photosynthetic activity and may explain the temporal variations of $\alpha^{\mathrm{B}}$ and $P^{\mathrm{B}}{ }_{\max }$ observed in the natural environment. Field studies have also shown that temporal variations in $\alpha^{\mathrm{B}}$ and $P^{\mathrm{B}}{ }_{\text {max }}$ are influenced by temporal variations in phytoplankton community structure (Harrison \& Platt 1980, Côté \& Platt 1983, Tillmann et al. 2000). The relationship between the photosynthetic activity of phytoplankton and available light may be due to specific characteristics of different species or groups. The optical absorption cross-section of photosynthetic apparatus, for example, varies between species (Falkowski et al. 1985) and determines $P^{\mathrm{B}}{ }_{\max }$ (Sakshaug et al. 1997). The efficiency with which absorbed light energy is converted into photosynthetic carbon is also an important factor which underpins the relationship between phytoplankton activity and irradiance (Langdon 1988) and which may vary between species.

In the present study, flagellates comprised a major part of the total cell biomass in April and June 1995, and November 1993 (Fig. 4), during which similar mean values of $\alpha^{\mathrm{B}}$ and $P^{\mathrm{B}}{ }_{\text {max }}$ were observed (Fig. 2). This apparent consistency of $\alpha^{\mathrm{B}}$ and $P^{\mathrm{B}}$ max may be attributable to similarities in the photosynthetic apparatus and quantum efficiency of flagellates during the different survey periods. Although total cell carbon during July 1995 differed in comparison to other survey periods in that diatoms, flagellates, dinoflagellates, ciliates and heterotrophic dinoflagellates were present in similar proportions (Fig. 4), this shift in the phytoplankton community structure did not result in significant differences in mean values of $\alpha^{\mathrm{B}}$ and $P^{\mathrm{B}}$ max when compared to those observed during the April, June, November 
and December surveys (Fig. 2). Observed values of $\alpha^{\mathrm{B}}$ and $P^{\mathrm{B}}{ }_{\max }$, however, represent the combined $P-E$ response of the autotrophic phytoplankton community. Differences between the $P$ - $E$ characteristics of different groups or species do not necessarily combine with changes in the community structure in such a way as to change the overall aggregate $P-E$ characteristics of a mixed natural phytoplankton assemblage.

The significantly higher $\alpha^{\mathrm{B}}$ and $P_{\max }^{\mathrm{B}}$ values observed during October 1994 (Fig. 2) coincide with a shift towards relatively high contributions of dinoflagellates to total cell carbon (Fig. 4). Multiple regression and correlation tests carried out on results from all incubation experiments showed that cell carbon concentrations of major phytoplankton groups were not significantly correlated with either $\alpha^{\mathrm{B}}$ or $P^{\mathrm{B}}{ }_{\max }$ (Table 3) and did not contribute to the prediction of $P$-E parameters (Table 4). Although multiple linear regression analysis (Table 4) did not confirm the possible importance of dinoflagellates in influencing $\alpha^{\mathrm{B}}$ and $P^{\mathrm{B}}{ }_{\max }$ (Figs. $2 \& 4$ ), we suggest that the high mean values of $\alpha^{\mathrm{B}}$ and $P^{\mathrm{B}}$ max during October 1994 (Fig. 2) may be attributable to interspecific differences between the $P-E$ characteristics of dinoflagellates and other major phytoplankton groups. Côté \& Platt (1983) showed values of $\alpha^{\mathrm{B}}$ for Bedford Basin phytoplankton were lower when dinoflagellates were dominant than when green flagellates or Dinobryon sp. were more abundant; the present study shows higher $P$-E parameters during periods in which dinoflagellates comprise a high proportion of phytoplankton. The results of the present study and those of Côté \& Platt (1983) indicate that the P-E characteristics of natural phytoplankton communities can be modified when dinoflagellates account for a major part of the phytoplankton biomass, although values of $\alpha^{\mathrm{B}}$ may be either higher or lower than when other groups dominate phytoplankton biomass.

Multiple regression analysis showed that $\alpha^{\mathrm{B}}$ could be predicted on the basis of total incident PAR, whilst $P_{\text {max }}^{\mathrm{B}}$ could be predicted by a linear combination of total incident PAR and sea-surface temperature (Table 4). These regressions do not, however, offer a particularly good means of predicting $\alpha^{\mathrm{B}}$ and $P^{\mathrm{B}}{ }_{\max }$ since the linear models derived explained only 43 and $57 \%$ of the variation in $\alpha^{\mathrm{B}}$ and $P_{\text {max }}^{\mathrm{B}}$ respectively (Table 4 ). The negative relationship of $\alpha^{\mathrm{B}}$ and $P^{\mathrm{B}}{ }_{\text {max }}$ with total incident PAR (Tables $3 \& 4$ ) contrasts with the generally accepted paradigm that $P^{\mathrm{B}}{ }_{\text {max }}$ decreases as phytoplankton become adapted to lower light levels (e.g. Falkowski 1980). The positive relationship of $P^{\mathrm{B}}$ max with temperature corresponds to the role of temperature-dependent enzymatic processes controlling $P_{\max }$ in microalgae (Geider \& Osborne 1992). Similar positive relationships between $P^{\mathrm{B}}{ }_{\max }$ and temperature have been reported previously in a number of field-based studies (e.g. Côté \& Platt 1983, 1984, Tillmann et al. 2000).

It is widely believed that the photosynthetic activity of phytoplankton is determined partly by adaptive responses to changes in the level and duration of exposure of cells to PAR (e.g. Falkowski 1980, Prézelin \& Matlick 1980, Sakshaug et al. 1997). $E_{\mathrm{k}}$ (Talling 1957) is considered to indicate acclimation or conditioning of phytoplankton cells to available PAR. Sakshaug et al. (1997) suggest that the value of $E_{\mathrm{k}}$ should increase with increasing PAR as a result of phytoplankton cells maintaining an optimum balance between light and dark reactions of photosynthesis.

The lack of a statistically significant difference in values of $E_{\mathrm{k}}$ observed between the survey periods in the present study (Fig. 2) indicates that photosynthetic activity of the phytoplankton in these coastal waters did not respond markedly to the seasonal changes in incident irradiance commonly observed in temperate northern latitudes. Moreover, variations in $E_{\mathrm{k}}$ were not significantly correlated to any of the environmental variables considered (Table 3) and none of these variables were found to contribute significantly to the prediction of $E_{\mathrm{k}}$ (Table 4). These observations contrast to previous reports of laboratory culture experiments which have identified changes in the $P$ - $E$ characteristics of phytoplankton and their pigmentation in response to changes in the intensity of PAR to which they were exposed (Marra 1980, Prézelin \& Matlick 1980) and the light/dark cycle of exposure to PAR (Gilstad et al. 1993). Adaptation of the photosynthetic apparatus of phytoplankton and their $P$ - $E$ characteristics has been observed in experiments in which cultures have been exposed to PAR of different intensities sustained over several days (e.g. Prézelin \& Matlick 1980, Garcia \& Purdie 1992). The mixing regime within the water column rarely results in exposure of phytoplankton cells to constant and sustained levels of PAR (Kirk 1994) and may therefore preclude physiological adaptations in the photosynthetic activity or photosynthetic apparatus of phytoplankton in their natural environment. It has been proposed (Uncles \& Joint 1982) that short vertical mixing timescales combined with high levels of water turbidity lead to conditions in which phytoplankton are exposed to high levels of PAR only for short periods which are insufficient to induce the physiological changes observed in laboratory studies of phytoplankton photoadaption or photoacclimation (e.g. Marra 1980, Prézelin \& Matlick 1980).

High levels of turbidity in near-shore marine environments considerably reduce the overall exposure of phytoplankton cells to irradiance in well-mixed waters (Uncles \& Joint 1982, Kirk 1994). In the study area (Fig. 1), the near-shore coastal waters to the south of Flamborough Head are mixed throughout the year, 
whilst more northerly regions tend to become thermally stratified from spring through to autumn (Horwood et al. 1982, Huthnance 1991, Tett \& Mills 1991). In the present study, the average level of exposure of phytoplankton cells to PAR ranges from 0.3 to $7.8 \%$ of surface incident PAR $\left(E_{0}\right)$ if mixing of phytoplankton cells through the entire depth of the water column and uniform vertical distribution of light-absorbing particles are assumed. During the summer period in which stratification may occur, the surface mixed layer is commonly less than $10 \mathrm{~m}$ and gradually deepens (Horwood et al. 1982). If it is assumed that exposure of phytoplankton to high levels of PAR near the surface is maximized by water column stratification which restricts vertical mixing to a $10 \mathrm{~m}$ surface layer, mean exposure to PAR ranges from 0.8 to $16.5 \%$ of $E_{0}$. Mean incident PAR during the spring and summer surveys (April to July 1995) ranged from 825 to $890 \mu \mathrm{mol}$ photons $\mathrm{m}^{-2} \mathrm{~s}^{-1}$ and mean exposure of phytoplankton to PAR is consequently limited to a range of up to ca $150 \mu \mathrm{mol}$ photons $\mathrm{m}^{-2} \mathrm{~s}^{-1}$ if stratification and a $10 \mathrm{~m}$ surface mixed water layer are assumed. During winter periods (November to December) the whole study area is well mixed and mean exposure to PAR was consequently only up to ca $30 \mu \mathrm{mol}$ photons $\mathrm{m}^{-2} \mathrm{~s}^{-1}$ under the conditions at the time and place of sample collection. Since the overall mean $E_{\mathrm{k}}$ value for the study is $176 \mu \mathrm{mol}$ photons $\mathrm{m}^{-2} \mathrm{~s}^{-1}$, exposure to light of phytoplankton cells moving randomly within the water column is unlikely to be sufficient for $P_{\max }$ to be attained, even when the incident irradiance is high and shallow stratification occurs. Inhibition of photosynthesis due to prolonged exposure to high levels of PAR is even more improbable.

On the basis of this study, it can be concluded that the $P-E$ relationships of natural phytoplankton assemblages in the near-shore UK coastal waters of the North Sea vary little, except when dinoflagellate species account for a large proportion of the total cell carbon. The turbidity of the water in the study area was also found to be an important factor in that the rapid attenuation of light by absorbing particles reduces exposure of phytoplankton to PAR to the extent that there is no evidence of photoadaptation to seasonal changes in the intensity of incident solar radiation.

Acknowledgements. The authors gratefully acknowledge the Masters and crews of RRS 'Challenger' for their co-operation and support during fieldwork programmes. The contributions of many colleagues on the LOIS project are also gratefully acknowledged, particularly Derek Harbour for enumeration of the phytoplankton samples. Comments by 2 anonymous reviewers helped to improve an earlier version of the manuscript. This study was funded under the Natural Environment Research Council Land-Ocean Interaction Study (LOIS) (Special Topic GST/02/740) and is LOIS publication number 825.

\section{LITERATURE CITED}

Brockmann UH, Laane RWPM, Postma H (1990) Cycling of nutrient elements in the North Sea. Neth J Sea Res 26:239-264

Côté B, Platt T (1983) Day-to-day variations in the springsummer photosynthetic parameters of coastal marine phytoplankton. Limnol Oceanogr 28:320-344

Côté B, Platt T (1984) Utility of the light-saturation curve as an operational model for quantifying the effects of environmental conditions on phytoplankton photosynthesis. Mar Ecol Prog Ser 18:57-66

Cullen JJ, Yang X, Macintyre HL (1992) Nutrient limitation of marine photosynthesis. In: Falkowski PG, Woodhead AD (eds) Primary productivity and biogeochemical cycles in the sea. Plenum Press, New York, p 69-88

Eppley RW, Reid FMH, Strickland JDH (1970) Ecology of the plankton of La Jolla, California, in the period April through September 1967. Bull Scripps Inst Oceanogr 17:33-42

Falkowski PG (1980) Light-shade adaptation in marine phytoplankton. In: Falkowski PG (ed) Primary productivity in the sea. Plenum Press, New York, p 99-119

Falkowski PG, Dubinsky Z, Wyman K (1985) Growth-irradiance relationships in phytoplankton. Limnol Oceanogr 30: 311-321

Fichez R, Jickells TD, Edmunds HM (1992) Algal blooms in high turbidity, a result of the conflicting consequences of turbulence on nutrient cycling in a shallow water estuary. Estuar Coast Shelf Sci 35:577-592

Garcia VMT, Purdie DA (1992) The influence of irradiance on growth, photosynthesis and respiration of Gyrodinium cf. aureolum. J Plankton Res 14:1251-1265

Geider RT, Osborne BA (1992) Algal photosynthesis: the measurement of algal gas exchange. Chapman-Hall, New York

Gieskes WWC, Kraay GW (1984) Phytoplankton, its pigments and primary production at a central North Sea station in May, July and September 1981. Neth J Sea Res 18:51-57

Gilstad M, Johnsen G, Sakshaug E (1993) Photosynthetic parameters, pigment composition and respiration rates of the marine diatom Skeletonema costatum grown in continuous light and a 12:12 h light-dark cycle. J Plankton Res 15: 939-951

Gowen RJ, Bloomfield SP (1996) Chlorophyll standing crop and phytoplankton production in the western Irish Sea during 1992 and 1993. J Plankton Res 18:1735-1751

Harrison WG, Platt T (1980) Variations in assimilation number of coastal marine phytoplankton: effects of environmental co-variates. J Plankton Res 2:249-260

Holligan PM, Harris RP, Newell RC, Harbour DS, Head RN, Lidley EAS, Lucas MI, Tranter PRG, Weekly CM (1984) Vertical distribution and partitioning of organic carbon in mixed, frontal and stratified waters of the English Channel. Mar Ecol Prog Ser 14:111-127

Holligan PM, Aarup T, Groom SB (1989) The North Sea: satellite colour atlas. Cont Shelf Res 9:667-765

Horwood JW (1978) Observations on spatial heterogeneity of surface chlorophyll in one and two dimensions. J Mar Biol Assoc UK 58:487-502

Horwood JW (1982) Algal production in the west-central North Sea. J Plankton Res 4:103-124

Horwood JW, Nicholls JH, Harrop R (1982) Seasonal changes in the net phytoplankton of the west-central North Sea. J Mar Biol Assoc UK 62:15-23

Huthnance JM (1991) Physical oceanography of the North Sea. Ocean Shore Manag 16:199-231

Jassby AD, Platt T (1976) Mathematical formulation of the relationship between photosynthesis and light for phytoplankton. Limnol Oceanogr 21:540-547 
Joint I, Pomroy A (1981) Primary production in a turbid estuary. Estuar Coast Shelf Sci 13:303-316

Joint I, Pomroy A (1993) Phytoplankton biomass and production in the southern North Sea. Mar Ecol Prog Ser 99:169-182

Keller AA (1988) An empirical model of primary productivity $\left({ }^{14} \mathrm{C}\right)$ using mesocosm data along a nutrient gradient. J Plankton Res 10:813-834

Kirk JTO (1994) Light and photosynthesis in aquatic ecosystems. Cambridge University Press, Cambridge

Kleinbaum DG, Kupper LL, Muller KE, Nizam A (1998) Applied regression analysis and other multivariate methods, 2nd edn. Duxbury Press, Pacific Grove, CA

Kovala PE, Larrance JD (1966) Comparison of phytoplankton cell numbers, cell volume, cell surface and plasma volume, per metre, from microscopic counts. Univ Washington Spec Rep 36:1-21

Lancelot C, Billen G, Barth H (1991) The Dynamics of Phaeocystis blooms in nutrient enriched coastal zones. Water Pollution Research Report of the Environmental Research \& Development Programme of the Commission of the European Communities (CEC), Brussels, number 23

Langdon C (1988) On the causes of interspecific differences in the growth-irradiance relationship for phytoplankton. II. A general review. J Plankton Res 10:1291-1312

Lederman TC, Tett P (1981) Problems in modelling the photosynthesis-light relationship for phytoplankton. Bot Mar 24: 125-134

Lorenzen CJ (1966) A method for the continuous measurement of in vivo chlorophyll concentration. Deep-Sea Res 13:223-227

Marra J (1980) Time course of light intensity adaptation in a marine diatom. Mar Biol Lett 1:175-183

Mills DK, Tett PB, Novarino G (1994) The spring bloom in the south western North Sea in 1989. Neth J Sea Res 33:65-80

Morris AW (1988) The estuaries of the Humber and Thames. In: Salomons W, Bayne BL, Duursma EK, Förstner U (eds) Pollution of the North Sea: an assessment. SpringerVerlag, New York, p 213-224

Mulvenna PF, Savidge G (1992) A modified manual method for the determination of urea in seawater using diacetyl monoxime reagent. Estuar Coast Shelf Sci 34:429-438

NERC (Natural Environment Research Council) (1992) North Sea Project CD-ROM. British Oceanographic Data Centre, Proudman Oceanographic Laboratory, Bidston Observatory, Birkenhead

Novarino G, Mills DK, Hannah F (1997) Pelagic flagellate populations in the southern North Sea, 1988-89 I. Qualitative observations. J Plankton Res 19:1081-1109

Editorial responsibility: Graham Savidge (Contributing Editor), Portaferry, Northern Ireland, UK
NRA (National Rivers Authority) (1993) The quality of the Humber estuary 1980-1990. National Rivers Authority, Bristol

Parsons TR, Maita Y, Lalli CM (1984) A manual of chemical and biological methods for seawater analysis. Pergamon Press, Oxford

Pennock JR, Sharp JH (1986) Phytoplankton production in the Delaware Estuary: temporal and spatial variability. Mar Ecol Prog Ser 34:143-155

Prézelin BB, Matlick HA (1980) Time-course of photoadaptation in the photosynthesis-irradiance relationship of a dinoflagellate exhibiting photosynthetic periodicity. Mar Biol 58:85-96

Reid PC, Lancelot C, Gieskes WWC, Hagmeier E, Weichart G (1990) Phytoplankton of the North Sea and its dynamics: a review. Neth J Sea Res 26:295-331

Sakshaug E, Bricaud A, Dandonneau Y, Falkowski, PG, Kiefer DA, Legendre L, Morel A, Parslow J, Takahashi M (1997) Parameters of photosynthesis: definitions, theory and interpretation of results. J Plankton Res 19: 1637-1670

Sanders RJ, Jickells T, Malcolm S, Brown J, Kirkwood D, Reeve A, Taylor J, Horrobin T, Ashcroft C (1997a) Nutrient fluxes through the Humber estuary. J Sea Res 37:3-23

Sanders RJ, Klein C, Jickells T (1997b) Biogeochemical nutrient cycling in the upper Great Ouse estuary, Norfolk, UK. Estuar Coast Shelf Sci 44:543-555

Shaw PJ, Purdie DA, de Freitas PS, Rees AP, Joint I (1998a) Nutrient uptake in a highly turbid estuary (The Humber, UK) and adjacent coastal waters. Estuaries 21:507-517

Shaw PJ, Chapron C, Purdie DA, Rees AP (1998b) Impacts of phytoplankton activity on dissolved nitrogen fluxes in the tidal reaches and estuary of the Tweed (North East UK). Mar Pollut Bull 37:280-294

Talling JF (1957) Photosynthetic characterization of some freshwater plankton diatoms in relation to underwater radiation. New Phytol 56:29-50

Tett P, Mills D (1991) The plankton of the North Sea - pelagic systems under stress? Ocean Shore Manag 16:233-257

Tillmann U, Hesse KJ, Colijn F (2000) Planktonic primary production in the German Wadden Sea. J Plankton Res 22: 1253-1276

Uncles RJ, Joint I (1982) Vertical mixing and its effects on phytoplankton growth in a turbid estuary. Can J Fish Aquat Sci 40(Suppl 1):221-228

Webb WL, Newton M, Starr D (1974) Carbon dioxide exchange of Alnus rubra: a mathematical model. Oecologia 17:281-291

Submitted: August 3, 1999; Accepted: October 17, 2000

Proofs received from author(s): June 5, 2001 